\title{
El informador de los atentados de ETA en las fotografías de prensa
}

\author{
Nekane PAREJO JiMÉNEZ \\ nekane@uma.es \\ Universidad de Málaga
}

Recibido: 30 de enero de 2014

Aceptado: 8 de septiembre de 2014

\begin{abstract}
Resumen
Las primeras imágenes sobre un atentado de ETA se publican en 1968 con motivo del asesinato de Melitón Manzanas. Desde esta fecha la representación fotográfica del informador de estos hechos en la prensa diaria ha experimentado diversas transformaciones en cuanto a sus funciones. A través de una evolución cronológica, en esta investigación se observarán los distintos roles que desempeña este profesional en el desarrollo de su cometido, así como sus emplazamientos. Las fotografías publicadas en los considerados periódicos tradicionales, La Gaceta del Norte, Hierro y El Correo, a los que se sumarán algunos de los que surgen con los inicios de la Transición como son Deia y Egin de cobertura regional y El País de ámbito nacional, conformarán la muestra de este estudio.
\end{abstract}

Palabras clave: Terrorismo, ETA, prensa, País Vasco, fotografía.

\section{The Reporter of ETA Attacks in Press Photos}

\begin{abstract}
The first images of an ETA bombing were published in 1968 following the Melitón Manzanas assassination. From this date, the photographic representation of the reporter of these facts in the daily press has undergone various changes in its function. Through a chronological evolution, this research will observe the different roles played by professionals in developing their mission as well as their location. The study sample consists of photographs published in newspapers considered traditional such as La Gaceta del Norte, Hierro y El Correo, and others which appeared at the beginning of the Transition, including Deia and Egin of regional coverage and El País of national coverage.
\end{abstract}

Keywords: Terrorism, ETA, press, Basque Country, photography.

\section{Referencia normalizada}

PAREJO JIMÉNEZ, Nekane (2015): "El informador de los atentados de ETA en las fotografías de prensa". Estudios sobre el Mensaje Periodístico. Vol. 21, Núm. 1 (enero-junio), págs.: 161-176. Madrid, Servicio de Publicaciones de la Universidad Complutense.

Sumario: 1.Introducción. 2. Fuentes y metodología. 3. Funciones y evolución del informador de los atentados de ETA; 3.1. Durante la Dictadura: garante para la credibilidad y sujeto señalizador del lugar del atentado; 3.2. Durante la Transición: en el ejercicio de su profesión delante y trás la cámara; 3.2.1. $\mathrm{El}$ informador presente; 3.2.2. El informador latente; 3.2.3. Informador presente y cadáver latente versus informador latente y cadáver presente; 3.3. Profesionalidad y limitaciones en la década de los 80; 3.3.1. La víctima y el fotógrafo coinciden en los encuadres in situ; 3.3.2. Nuevo rol: ser el primero y conseguir la imagen más impactante; 3.4. A partir de los 90: vehículo para la autocensura. 4. Conclusiones. 5. Referencias bibliográficas.

\section{Introducción}

Entre 1960 y marzo de 2010, fecha en la que se produce el último atentado, la banda terrorista ETA mató a 857 personas. En un lapso de tiempo tan amplío las formas de acometer el tratamiento mediático han ido variando ostensiblemente. Por este motivo una aproximación a la figura del informador resulta necesaria. El estudio de las funciones que este desempeña en la fotografía de prensa española delante y detrás de la 
cámara es nuestro propósito prioritario. Entendemos por informador a aquel que comunica las noticias por medios escritos o visuales y por tanto, tendrán cabida redactores y reporteros gráficos. En concreto serán las fotografías de estos atentados las que le otorguen la cobertura precisa. Paradójicamente de la primera muerte, la de la niña Begoña Urroz que se produce en junio de 1960, no se publica ninguna imagen, lo cual es altamente significativo.

En este medio siglo objeto de investigación, los cambios históricos y sociopolíticos dan cuenta de una serie de instantáneas marcadas por un mismo objetivo, cubrir informativamente, en este caso un acto terrorista que se va repitiendo. Pero sí en esencia la finalidad del informador es mostrar unos hechos, las formas de visualizarlo varían. Indicadores como su ausencia total del encuadre frente a una presencia cuya misión cambia en función de cada etapa histórica, llevan a determinar que su cometido se ajusta a lo expuesto en la premisa inicial, poner al corriente al lector de prensa, pero que a su vez su imagen ha sido ocultada o mostrada dependiendo de las necesidades de cada época.

\section{Fuentes y metodología}

Con el fin de lograr la mayor representatividad, los diarios seleccionados se corresponden con los de mayor difusión y están presentes todos los espacios ideológicos. Se trata de cabeceras de referencia que por un lado, aglutinan los considerados periódicos tradicionales La Gaceta del Norte, Hierro y El Correo, a los que se sumarán algunos de los que surgen con motivo del final de la Dictadura de Franco en los inicios de la Transición como son Deia y Egin de ámbito regional y El País de cobertura nacional. A través de estos diarios, de distintas tendencias, se constatará la evolución de la presencia del informador mediante tomas en las que desempeña un rol que, a veces, se ajusta al desarrollo de su labor profesional, pero que otras se aleja, e incluso llega a pasar desapercibido. Además, se advertirán claros sesgos ideológicos patentes en las fotografías de la muestra seleccionada en función de cada periódico.

Si bien partimos de un universo compuesto por todas las tomas de los atentados de ETA, la muestra seleccionada acogerá como unidad de análisis aquellas fotografías de atentados mortales que se publicaron los tres días posteriores al suceso.

Las categorías a través de las cuales se clasificarán las tomas será por un lado, la presencia del informador en el encuadre fotográfico, lo que consideraremos representación evidente, y por otro, la percepción sutil mediante la constatación de huellas enunciativas y marcas de autor que denominaremos presencia latente. Este mismo criterio servirá para clasificar la representación del cuerpo de la víctima. Las distintas permutaciones que estas variables propician a través de la historia darán cuerpo a este análisis de contenido en una variante de carácter cualitativo y comparativo. Un estudio en el que destacamos aquellas imágenes que se han constituido en un modelo a seguir por el resto de las publicaciones.

Nuestra hipótesis de partida radica en cómo la labor del informador de los atentados de ETA corre paralela a los cambios sociopolíticos y tecnológicos que se han ido instaurando en la sociedad española en los 50 años durante los que se producen. Esta situación conforma una evolución circular del tratamiento periodístico y del papel que 
desempeñan sus artífices que no siempre se han regido por los principios que defiende José Luis Dader, que establecen que el ciudadano "requiere de unos proveedores de la información [...] Para ello deberán seleccionar datos en función de su relevancia, certificar mediante pruebas razonables la exactitud de sus noticias y no escamotear datos a sus audiencias" (2007: 50).

\section{Funciones y evolución del informador de los atentados de ETA \\ 3.1. Durante la Dictadura: garante para la credibilidad y sujeto señalizador del lugar del atentado}

En los sesenta y principios de los setenta el lector de prensa está familiarizado con una imagen del informador que comparte encuadre con el entrevistado. Micrófono en mano y en el ejercicio de su profesión se van inmortalizando perfiles de periodistas que de una forma distendida conversan con un personaje. En esos momentos la censura es muy fuerte y, como contrapeso a esa situación y a una opinión pública cada vez más crítica, insertar en la fotografía al artífice de la entrevista otorga credibilidad al hecho. No es casualidad que se repita este esquema donde el informador parece ratificar las palabras de Roland Barthes "Yo he estado aquí".

El primer testimonio es fiel al modelo instaurado por el franquismo en la prensa tradicional. En él vemos como el director General de Seguridad, Eduardo Blanco, es entrevistado por un redactor de La Gaceta del Norte con motivo del asesinato de Eloy García el 29 de agosto de 1972. La toma muestra un plano medio de ambos sentados en un sofá. El fotógrafo aún no puede retratar a la víctima en el lugar de los hechos, que tampoco se reproduce con indicios de lo que ha pasado. Los diarios se limitan a imprimir imágenes del pasado, -en esta ocasión se reproduce una de la víctima rodeada de su familia con motivo de la Comunión de su hijo menor y otra en la que le acompañan sus compañeros de trabajo-, o fotografías del lugar del atentado, difíciles de ubicar en el tiempo. Estas no poseen correlación alguna con el hecho y serán una serie de soportes gráficos los que narren lo que supuestamente ha sucedido. La au-

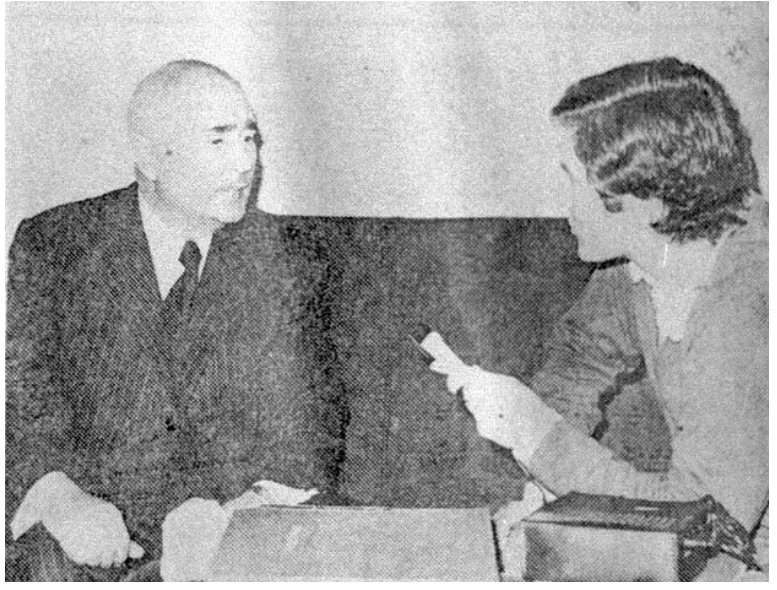

Fuente: La Gaceta del Norte, 31 de agosto de 1972 sencia de la víctima conlleva la necesidad de insertar contenidos que le confieran consistencia. De ahí los numerosos encuadres en los que la viuda toma protagonismo, así como el que nos ocupa, que muestra al director General de Seguridad dando su versión de los hechos ante un informador que funciona como el elemento que sirve para confirmar la noticia. Será el cambio de contexto político, el que establezca la desaparición de este modelo. 
Otro arquetipo propio de los últimos años de la Dictadura es aquel en el que el informador reemplaza a la víctima en el encuadre fotográfico. Hasta el momento el espacio del asesinado permanecía sin señal alguna o había sido marcado con un soporte gráfico, normalmente una flecha. De ahí la importancia de una presencia humana, aunque todavía ni indica, ni escenifica. Como un personaje anónimo, de espaldas y a una distancia narrativa que va desde un segundo término a un plano alejado que le hace irreconocible, se le localiza en fotografías como las editadas a raíz del asesinato de Manuel Vázquez Pérez por La Gaceta del Norte y El Correo el 4 de junio de 1974. El pie de foto se hace eco de esta situación: "Nuestro redactor se ha situado aproximadamente en el lugar en el que encontró la muerte el guardia civil Manuel Vázquez Pérez". Este tipo de toma evidencia la falta de imágenes que muestren no sólo el suceso, sino sus posibles secuelas. No se aprecia ningún desperfecto, solo a una persona en un lugar solitario en el que parece no haber ocurrido un acto violento.

Antes el periodista certificaba

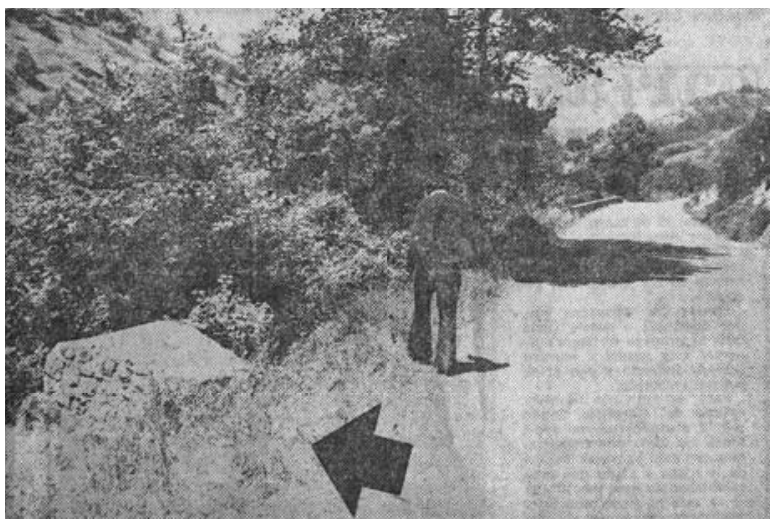

Fuente: La Gaceta del Norte, 4 de junio de 1974 el suceso mediante su presencia como entrevistador, ahora, desde el anonimato, funciona como un mero estandarte visual del sitio donde se produjo el asesinato. Esto nos hace tomar conciencia de la noción del tiempo transcurrido desde el atentado. En concreto, cuándo se produce su llegada. La falta de signos que nos remitan al hecho son una muestra de que el informador en 1974 no se desplaza a tiempo para registrar el suceso.

En cualquier caso, ni la presencia del entrevistador para autentificar una situación, ni como marca visual del lugar de los hechos, fueron modelos con gran profusión. Lo habitual era que pasara desapercibido, no sólo en lo que se refiere a los contenidos del encuadre, sino también a la hora de apreciar un estilo identificable. La foto de autor no tiene cabida todavía, son las agencias las encargadas de firmar una imágenes anodinas en las que el reportero no tiene presencia ni delante, ni detrás de la cámara, salvo las excepciones expuestas.

\subsection{Durante la Transición: en el ejercicio de su profesión, delante y tras la cámara} Tras la muerte de Franco emergen nuevos periódicos que irán instaurando nuevos tipos de representación en los que el informador va tomando posiciones a ambos lados de la toma fotográfica'. Si nos referimos a su presencia en el encuadre, en el transcurso

${ }^{1}$ El País surge en mayo de 1976, Deia el 8 de junio de 1977 y Egin en septiembre del mismo año. Estos nuevos diarios, con sus renovados planteamientos, harán hincapié en un claro distanciamiento en cuanto a sus contenidos y puntos de vista a través de unos fotógrafos con poder para decidir sobre estos aspectos. Para ampliar esta información puede consultarse la tesis doctoral inédita de FERNÁNDEZ BAÑUELOS, J. I. (1997). 
de 1977, encontramos ejemplos que combinan muestras de continuidad con aperturismo, independientemente del diario de publicación. Es el caso de dos fotografías similares de El País y La Gaceta del Norte del 23 de junio de 1977 a causa de la muerte de Javier de Ybarra. En ambas el hermano de la víctima, Enrique de Ybarra, está leyendo un comunicado a una prensa latente que se delata por la inclusión en el encuadre de una mano que sujeta un micrófono. La diferencia con las referencias anteriores estriba en que ahora se omite deliberadamente la fisonomía del periodista. Con el registro de su herramienta de trabajo es suficiente para dejar constancia de una presencia que sigue remitiendo a un instante muy posterior al suceso.

Hasta el momento sólo se ha visto la imagen del periodista como marchamo de autenticidad o como marca visual. El 24 de junio de 1977 y con motivo del mismo atentado, Deia ofrece una toma en la que por primera vez se hace patente la figura del fotógrafo en el ejercicio de su profesión. Invirtiendo el punto de vista del resto de los medios, que reproducen el entierro desde la puerta de la iglesia, el reportero registra el ataúd en primer término y capta a varios colegas, apenas perceptibles. Dada su situación se puede asegurar que la aparición de estos compañeros es casual, que su objetivo es aproximarse más al ataúd. Sin embargo, la instantánea nos lleva a tener en cuenta el hecho de que este reportero se sitúa deliberadamente en una posición alejada de sus colegas para conseguir un punto de vista distinto. Esto implica el surgimiento de una serie de marcas de autor en las fotografías que se identifican con los nuevos diarios. A la par la firma de la agencia es sustituida por la del fotógrafo. Las primeras muestras son las instantáneas próximas y emotivas de Deia del atentado al Presidente de la Diputación Provincial de Vizcaya en Guernica, Augusto Unceta, el 11 de octubre de 1977, o las impactantes y novedosas tomas ${ }^{2}$ de este mismo atentado que reproduce Egin el 9 de octubre de 1977 de los guardias civiles, Antonio Hernández Fernández y Ángel Rivera Navarro, que escoltaban a Unceta.

\subsubsection{El informador presente}

A finales de 1978 los encuadres donde el informador está presente se convierten en un contenido habitual, también en algunas cabeceras de la prensa tradicional, aunque con un planteamiento distinto. Mientras los diarios más antiguos, sobre todo La Gaceta del Norte, dirigen sus objetivos hacia un periodista, sin señas de identidad, centrado en entrevistar a testigos, los nuevos se concentran en retratarlo de forma reconocible en plena acción y con signos identificativos de su profesión. En este sentido, el 3 de noviembre de 1978 La Gaceta del Norte y Deia tras el asesinato de José Legasa Ubiria publican sendas fotografías. El primero reproduce a un grupo de personas al fondo. Se desconoce su identidad, si no es a través del pie de foto: "Dos testigos conversan con los periodistas". Deia, sin embargo, muestra a varios reporteros de espaldas, micrófono en mano, próximos al coche fúnebre. Una comparación ratifica las premisas expuestas. En el primer caso, el lector es informado de la ocupación de los integrantes de la toma mediante texto, en el segundo este mecanismo resulta innecesario, la proximidad de los micros y sus movimientos constatan una acción evidente.

2 Son las primeras imágenes de cadáveres en el lugar de los hechos después de las registradas año y medio antes a Manuel Albizu. 
Otro rasgo diferenciador de estos dos modelos es la forma reposada que caracteriza al informador de los diarios tradicionales que cuenta con una vía directa de conexión con el entrevistado, mientras los registros de los nuevos periódicos incluyen una gran variedad de dificultades para conseguir su cometido. Allegados, guardaespaldas, otros reporteros... obstaculizan su trabajo.

Se puede establecer una última disparidad remitiéndonos al concepto de espacio y tiempo. Las imágenes de los primeros se vinculan con el lugar de los hechos a posteriori, mientras las de los nuevos periódicos se sitúan durante las exequias. Así encontramos una instantánea de El País el 17 de noviembre de 1978 en la que la viuda de Francisco Mateu Canovas es retratada por varios fotógrafos cámara en alto. Nuevamente, aunque más próximos y reconocibles, se observa cómo los fotógrafos son registrados por otro colega. Inicialmente justificábamos esta circunstancia en aras de un reportero más autónomo que busca mostrar en la imagen su personalidad mediante un punto de vista diferente. A esto se debe sumar el incremento del número de reporteros gráficos ya que las fotografías se están convirtiendo en un elemento indispensable para los diarios. Mario García en un estudio acerca de la remodelación de los periódicos se escuda en el lector: "Los lectores quieren cada vez más fotos en el periódico, y en consecuencia, los directores incluyen cada vez más páginas de fotos" (García, 1984).

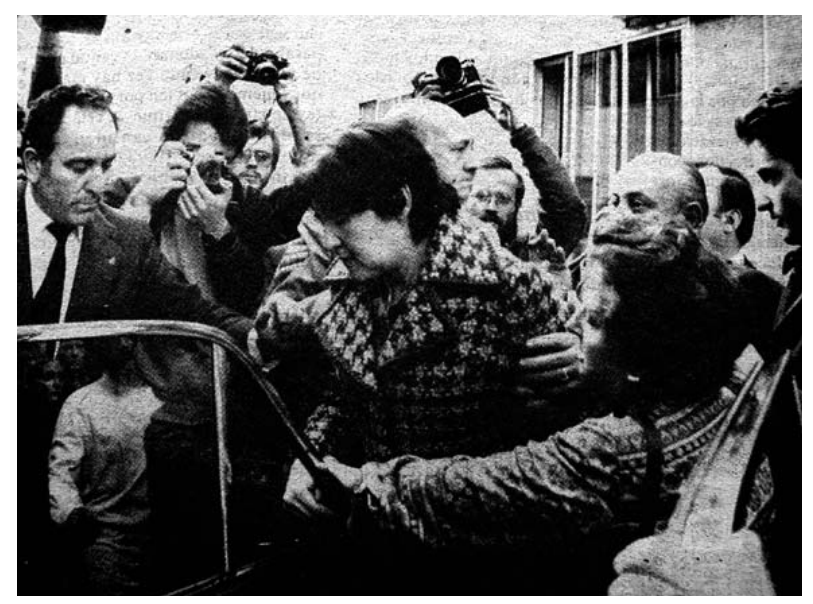

Fuente: El País, 17 de noviembre de 1978

\subsubsection{El informador latente}

Con respecto a la presencia del reportero tras la cámara, se entreveía una transformación de la mano de los nuevos diarios que habían comenzado a publicar unas tomas que irán marcando la pauta y servirán de modelo para el resto. Fotografías, decíamos, en las que prima la cercanía, la emotividad o la acción y en las que la presencia humana es imprescindible.

En 1978 el fotógrafo seguirá siendo un testigo de excepción como señala Rosa Olivares: "Víctima, culpable y testigo, forman, formamos, un triángulo cuyos ángulos son inseparables. Uno se justifica y existe por el otro, y el tercero con su mirada y presencia casi siempre muda, define la existencia de los otros dos. Ese testigo, el fotógrafo, el que mira y el que consigue que todos nosotros miremos a través de sus ojos" (2000:9). Él tendrá la capacidad de guiar algunas de las acciones que ocurren en el lugar de los hechos. Deia y Egin el 5 de diciembre de 1978, publicará sendas fotografías del atentado a Gabriel Alonso Perejil en San Sebastián. Egin muestra a dos ca- 
milleros, uno ajeno al reportero y un segundo, que mira fijamente al objetivo, sujeta una sábana y parece dilatar su acción de depositarla sobre el fallecido, aguardando una señal del fotógrafo. Mientras, en la de Deia, posterior en el tiempo, parece esperar el instante para elevar la camilla con la víctima. Siguiendo el patrón marcado, este diario, edita una toma el 16 de mayo de 1980 del atentado en el que fallecieron Dionisio Villadangas, José Manuel Rodríguez y Jesús Holgado. Las circunstancias son idénticas, el chico mira fijamente a cámara esperando el aviso.

El hecho de que el reportero se haya convertido en alguien capaz de organizar y decidir los movimientos de los retratados le dota de un poder hasta ahora desconocido que permite al lector acercarse más al instante de la muerte. Lógicamente, el valor periodístico de la toma se incrementa si el cadáver de la víctima permanece allí donde murió y perfectamente visible. Nos encontramos ante un signo del desafío que supone conseguir la foto de mayor impacto. Posteriormente, en ocasiones, el fotógrafo no dudará en descubrir el rostro del asesinado levantando el mismo la sábana que lo cubre. Obviamente no hay constancia gráfica de esta acción ${ }^{3}$. De momento, en el 78 y en el bienio 79-80 lo que se aprecian son imágenes más o menos sutiles que captan un rol basado en dirigir las acciones de los componentes de su futuro encuadre.

En este bienio desaparecen casi íntegramente las tomas en las que el periodista entrevistaba a familiares y testigos. También dejan de publicarse aquellas en las que el reportero era un mero objeto que servía para señalizar el lugar de los hechos. Como se ha visto, su labor está detrás de la cámara intentando conseguir el punto de vista más próximo y vinculado con el suceso. Esto no quiere decir que su imagen se haya suprimido totalmente de las fotografías. La diferencia estriba en que ahora se le capta, pero no ratifica la información mediante un posado. Además, una primera visualización basta para identificarle.

\subsubsection{Informador presente y cadáver latente versus informador latente y cadáver presente}

El fotógrafo ha cobrado protagonismo detrás y delante de la cámara, aunque se le registre en ocasiones de espaldas o en un segundo plano. Su posición no es óbice para que se le reconozca. La mayor parte de las tomas, de espaldas, pertenecen a diarios tradicionales. Así le encontramos registrando el cortejo fúnebre de los policías Jesús Hernández Ortega, José Antonio Merendiano Ruiz y Sergio Canal Canal en La Gaceta del Norte del 5 de octubre de 1980. Se trata de una instantánea precursora en el uso de las bandas negras para ocultar la identidad de los compañeros de los fallecidos que llevan el féretro a hombros. Es una imagen que indica que el objetivo de la censura ya no es la víctima, sino las posibles futuras víctimas. Algo impensable poco tiempo antes, cuando el periodista se retrataba con los familiares, testigos, compañeros... del asesinado mientras les entrevistaba. Este mismo diario publicará un encuadre similar un mes después, el 18 de noviembre de 1980, de los funerales de Juan García León.

${ }^{3}$ En películas de ficción como El ojo del fotógrafo de Iñaki Dorronsoro, Camino a la perdición de Sam Mendes, o El ojo público de Howard Franklin se puede encontrar una interpretación muy acertada de esta situación. 
Las tomas frontales del fotógrafo en acción se ubican principalmente en los nuevos periódicos como la de Deia del 13 de enero de 1979 de los funerales del policía municipal Bienvenido Romero Montejo. También el reportero de El País deja constancia de la presencia frontal de un colega el 13 de diciembre de 1979 junto a una señora santiguándose.

Otro aspecto destacable es la evolución que sufre la presencia de los fotógrafos en el lugar de los hechos. A pesar de que tras la muerte de Franco se produce un incremento del número de reporteros, y cada vez acuden con mayor premura y son capaces de registrar al cadáver in situ, a penas si existen imágenes que delaten su presencia en el lugar del suceso. Hasta ahora sus apariciones se localizan en los funerales o en el escenario del crimen a posteriori.

A partir del bienio 79-80 se le retrata en el lugar del atentado cuando todavía las secuelas son apreciables. El País del 19 de marzo de 1980 publica una toma donde se aprecia en primer plano la motocicleta que portaba el explosivo que acabó con la vida del escolta José Luis Ramírez Villar, y tras ella un fotógrafo de frente manipulando los mecanismos de su cámara. Debido a las numerosas imágenes del cadáver in situ que se publican en estas fechas, sabemos que el reportero coincide en el mismo espacio con la víctima, pero no será hasta 1981 cuando el lector pueda verlos en el mismo encuadre.

De momento, la toma que más se acerca la edita La Gaceta del Norte el 26 de mayo de 1979. En ella se ve un coche militar cuyas ventanillas han sido tapadas por una manta para ocultar los cuerpos sin vida de Jesús Ávalos Jiménez, Luis González Ortigüela, Agustín Laso Corral y Lorenzo Gómez Borrero. Tras el coche varios fotógrafos de frente al objetivo de su compañero de La Gaceta del Norte. Nuevamente nos encontramos ante un pie de foto explicativo: "El coche en el que circulaban los militares asesinados. Cuando fue obtenida aún se encontraban en el interior los cuerpos". Podemos establecer que se trata de un fotógrafo presente en la imagen frente a un cadáver latente.

\subsection{Profesionalidad y limitaciones en la década de los 80}

En este periodo la representación gráfica del reportero mantendrá un esquema basado en su profesionalidad donde la cámara, omnipresente, se convertirá en su firme aliada. La mayor transformación se sitúa en el espacio en el que se le retrata. Si hasta el momento existía un predominio de las tomas en las exequias, serán ahora las del lugar del suceso las protagonistas. Esta circunstancia no implica que las primeras hayan desaparecido. Por un lado, se mantienen las clásicas imágenes en la capilla ardiente en las que se sitúa un fotógrafo de espaldas mientras el fallecido permanece en el ataúd, como las de Egin y El País con motivo del asesinato de José Raimundo Moya el 6 de marzo de 1981. Por otro, se produce una evolución basada en una elaborada composición de la imagen. Es el caso de la instantánea de Deia del 11 de septiembre de 1988 donde la posición de dos reporteros sirve para subencuadrar una escena en la que se ve como son transportados los féretros de Martín Martínez Velasco y Pedro Antonio Fonte Salido.

Una particularidad novedosa que vincula al fotógrafo con el registro de las exequias es la oposición por parte de familiares y allegados a que éstas se retraten. Ante esta si- 
tuación el reportero convierte en centro de interés de sus instantáneas los enfrentamientos con los informadores. El 17 de junio de 1981 El País y El Correo editan una imagen donde observamos una persona consternada y otra con claras muestras de enfado. Debajo un ilustrativo pie de foto: "Ayer se celebró el funeral en San Sebastián, en el curso del cual el padre de la víctima protagonizó un incidente al dirigirse a varios informadores en términos insultantes".

La actitud más extrema corre a cargo de aquellos familiares que prohíben totalmente reproducir cualquier aspecto relacionado con el funeral. Esto implica una carencia de imágenes y, a la par, la publicación de tomas muy tangenciales a los hechos como las de Egin del entierro de la fiscal Carmen Tagle el 14 de septiembre de 1989 donde los familiares impidieron el acceso a los periodistas ${ }^{4}$. Se trata de un factor más, que influye en el desplazamiento de la prensa al lugar del asesinato que se encuentra cada vez más poblado y cuyo principal referente es el cadáver in situ. Esta situación conlleva un incremento en ese espacio del número de reporteros y por tanto, un aumento de las posibilidades de que el encuadre recoja, no sólo al cadáver sino, como ocurría en los funerales, a algún colega.

Se suceden imágenes que insertan la figura del fotógrafo con contenidos y acciones diversas. A veces la razón de su presencia está relacionada con su ubicación en el centro de la acción, lo cual impide sacarle del encuadre. Es el caso de la imagen de Deia del atentado a Antonio Torrón Santamaría del 20 de julio de 1984 donde el reportero comparte plano con algunos curiosos que se han acercado al lugar del asesinato. En otras, el motivo a retratar es más evidente, como en las tomas en las que los restos del suceso se convierten en el centro de interés como para el fotógrafo situado en el portal de la casa de Alberto Aznar Félix tras su asesinato, o el encuadre de Deia del 16 de junio de 1981 en el que el cámara está reproduciendo el charco de sangre de Ma José García Sánchez.

En las imágenes anteriores el informador gráfico o se encontraba a la espera o registraba a posteriori las huellas del suceso. Pero como se ha expuesto, en esta década son habituales tomas en los que la víctima y un reportero comparten encuadre, aunque no siempre a cara descubierta. Lo habitual es que entre ambos mediara una sábana que tapaba al asesinado, como en la publicada por El Correo, Deia y Egin el 13 de septiembre de 1989 en la que un cámara y su ayudante están retratando el cuerpo sin vida de Carmen Tagle. En una situación similar encontramos la editada por Egin el 26 de mayo de 1988 donde se recoge a un fotógrafo tras la hermana de Sebastián Azpiri que está levantando la sábana que cubre su cuerpo sin vida.

\subsubsection{La víctima y el reportero coinciden en los encuadres in situ}

Se ha visto como el reportero va acercándose progresivamente para conseguir captar el instante más próximo al momento del atentado. Será el 8 de febrero de 1981 cuando El País imprima una toma que determinará un nuevo modelo de representación del in-

4 Este mismo diario junto con El Correo y Deia habían insertado un día antes una imagen de la víctima tendida en el lugar de los hechos cubierta con una manta. 
formador. En el mismo marco concurren uno o varios fotógrafos y el cuerpo sin vida de la víctima en el mismo sitio donde falleció. En la instantánea de El País se aprecia a cuatro reporteros que desde una angulación casi cenital y muy cercana registran a José $M^{a}$ Ryan tumbado de perfil y en primer término. Nunca el protagonismo del informador gráfico había sido tan destacado.

Este patrón fotográfico se asienta con otras imágenes como la de Deia del 26 de abril de 1986 que coincide con la anterior en la posición frontal del informador en el encuadre respecto al reportero que está fuera de él, en la angulación y en su cercanía ${ }^{5}$.

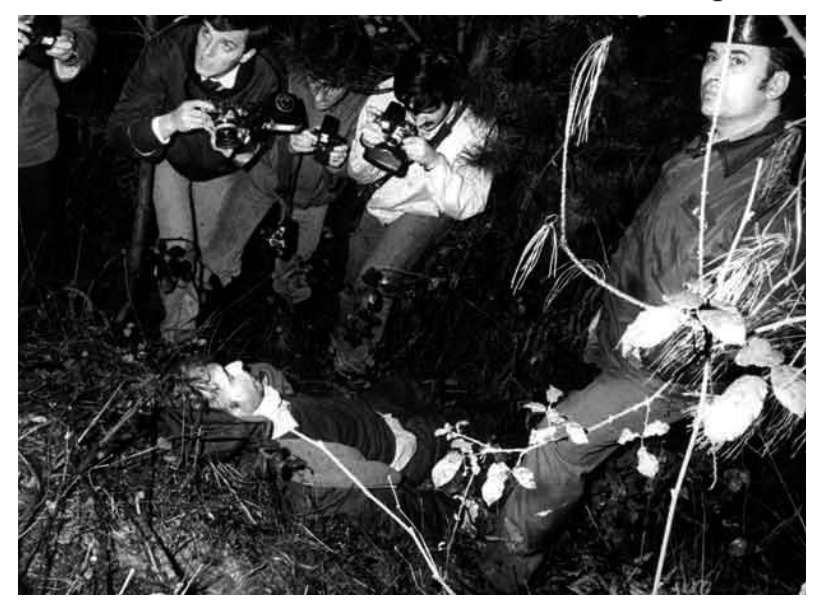

Fuente: El País, 8 de febrero de 1981

\subsubsection{Nuevo rol: ser el primero y conseguir la imagen más impactante}

Conseguir llegar el primero para capturar la imagen más cercana al momento de la muerte se ha convertido en un objetivo primordial. Recordemos que el fotógrafo de la Transición parecía no tener prisa por personarse en el escenario del atentado. En ocasiones llegaba deliberadamente tarde debido a que la foto del cadáver no se iba a publicar. Poco después surge la necesidad, por parte de algunos periódicos, de editar una toma más limítrofe con el suceso y que no remita a los funerales. Así emergen una serie de imágenes del muerto en el depósito. A pesar de los obstáculos, el reportero no duda en saltar vallas o colarse por las ventanas de un edificio cerrado para lograr esa instantánea. Más tarde su prioridad será llegar a tiempo para poder captar el cuerpo sin vida de la víctima in situ. Ahora el reto estriba en ser el primero que retrate el cadáver y consecuentemente ser el que más se aproxime al momento en el que se produjo el atentado. En este sentido se articulan una serie de pies de foto altamente significativos, como "Momento en el que se produjo el atentado" (Deia, 10 abril 1979) o "Tres policías nacionales momentos después de que fueran asesinados" (El Correo, 10 abril 1979).

El reportero es uno de los primeros en acceder al lugar del delito, quien se ha convertido en un sujeto rápido que debe no sólo adelantarse a los demás en la ejecución del disparo fotográfico, sino además enterarse antes. También mediante el texto y los pies de foto puede certificarse esta competición por conocer el hecho antes que otros,

${ }^{5}$ El 19 de mayo de 1985 La Gaceta del Norte había registrado una imagen en la que el reportero se encontraba en una posición similar, muy próximo al fallecido y justo encima de su rostro. Se trata de una toma en la que se recoge al fotógrafo retratando el cuerpo sin vida de Mikel Goikoetexea (una de las primeras acciones del Gal) a través de un orificio situado en la tapa del ataúd. El escenario es distinto, pero refleja perfectamente la forma de trabajar de los informadores de la época basada en acercarse lo más posible. 
incluso antes que la familia o que la Policía. En este sentido, El Correo del 23 de enero de 1980 publica una instantánea del interior de un bar cuyo propietario es la víctima, Alfredo Ramos Vázquez. Bajo ésta se reafirma el mérito que se otorga a la inmediatez: "Al fondo, una de las hijas, cuando aún no sabía nada del asesinato de su padre". El diario Egin del 31 de marzo de 1982 va más allá cuando edita la imagen del cadáver de Ramiro Carasa Pérez, tendido en la hierba boca abajo con la manos atadas sobre la espalda. El valor añadido de la toma es llegar antes que la Policía: "Un miembro de la redacción de este periódico dijo que poco antes de las ocho y media de la noche se recibió la llamada telefónica y se dio aviso a la Policía, al tiempo que se desplazan al lugar un redactor y un fotógrafo. Volvieron al periódico y recibieron una llamada de la Policía en la que se solicitaba les indicasen a ellos el lugar exacto donde se encontraba el doctor Carasa".

En años anteriores se había expresado la magnitud del fotógrafo como organizador de la toma. Su presencia latente se evidenciaba a través de miradas directas al objetivo de su cámara en espera del instante oportuno para ejecutar una acción. Esta situación permanecerá durante la década de los 80 , pero ahora el reportero no sólo es capaz de detener el tiempo para simular una acción más próxima al suceso, sino que también está preocupado por mostrar los hechos tal cual. Para ello sabe que debe mantenerse alerta para conocerlos y fotografiarlos antes de que se produzca alguna manipulación sobre el cuerpo de la víctima. Continuando con el atentado anterior, Egin publica dos instantáneas una junto a otra. Una, la comentada, muestra a la víctima, como se encontró, mientras en la otra, lo vemos boca arriba.

La cualidad que los nuevos editores de prensa valorarán más de los informadores gráficos va a ser la capacidad de conseguir no sólo la imagen más cercana en el tiempo al suceso, sino también la más impactante. El reportero cuenta con algunos mecanismos para lograrlo. Dos de ellos se han visto aquí, llegar antes que los demás y conseguir una imagen más acorde con la realidad de la noticia y en la que no se hayan efectuado cambios, u organizar pequeños detalles del escenario del delito que den muestras de un acercamiento en el tiempo entre registro de la imagen y el instante del atentado.

Otra fórmula que vincula directamente al fotógrafo con las exigencias del editor es la libre selección de los contenidos mediante el punto de vista. Su poder radica en situar el motivo principal donde interesa al diario en cuestión. Esta situación implica que dos periódicos pueden cubrir el mismo atentado con los mismos contenidos, pero desde perspectivas opuestas. Una muestra son las fotografías que publican La Gaceta del Norte y Deia el 23 de marzo de 1982 de la muerte de dos policías, Agustín Martínez Pérez y Alfonso Maside Bouzo y la novia de uno de ellos Cristina Mónica Illarramendi. En ellas apreciamos a los asesinados bajo la mesa en la que estaban comiendo cuando ocurrió el atentado. La diferencia estriba en que el reportero de Deia prioriza a los cadáveres en primer plano, mientras el de La Gaceta del Norte se sitúa en el punto opuesto colocando como centro de interés la mesa en primer término y tras ella muy al fondo los cuerpos sin vida.

El poder del reportero responde en estos momentos a la definición de Emilio Romero: "El reportero gráfico, para algunas gentes, se ha vuelto peligroso. Sencillamente 
ya no tiene la exclusiva mentalidad de fotografiar, sino de contar en la propia imagen" (Romero, 1992:112).

Un nuevo modelo de representación gráfica que se incorpora en los 80 es la captación de las ruedas de prensa. Este tipo de imagen que completa a la del lugar de suceso, a la de la víctima, la capilla ardiente, las exequias, etc. cuenta con un protagonista inicial, que es una o varias autoridades informando sobre el hecho. El contenido más frecuente, exceptuando al representante de la familia o autoridad en cuestión, es el micrófono, cuyo número sirve para evaluar el interés despertado por cada atentado. Una de las más numerosas corresponde al de Hipercor el 20 de junio de 1987. Egin edita dos encuadres, el de la rueda del prensa del Gobierno Civil en Barcelona y la del estado de los heridos del director de la Residencia Valle de Hebrón.

La rueda de prensa más singular que se retrata pertenece a El País del 18 de abril de 1982 donde se ve a cuatro miembros de ETA cubiertos por una capucha negra tras una mesa leyendo un comunicado. Se trata de una fotografía significativa ya que hasta ahora los miembros de la banda terrorista aparecían en las fotografías como individuos buscados o muertos en su propia acción. La transformación gravita en el hecho de que no se fomenta su búsqueda a través de la imagen, sino su papel como informantes, como aquellos que ofrecen una exclusiva a la prensa.

\subsection{A partir de los 90: vehículo para la autocensura}

A comienzos de la década de los 90 se registra un nuevo cambio, en cuanto a los contenidos de las fotografías. El rol que desempeña el informador de este periodo es esencial para explicar el desarrollo que se ha alcanzado en la sociedad en lo que a recepción de la información se refiere. Además, tras el asesinato de Miguel Ángel Blanco Villar "los medios reivindican la unidad de las fuerzas democráticas y funcionan como un instrumento más contra la lucha antiterrorista" (Caminos, 2013a:6).

El fotógrafo empieza a reflexionar sobre la sensibilidad de los demás. Juan Ignacio Fernández que trabajó como fotógrafo en El Correo durante la Transición y en la actualidad continua su labor informativa como editor jefe de fotografía de ese mismo diario señala: "El fotógrafo es sistemático. El primer objetivo es mostrar las consecuencias directas: fotografiar el hecho en sí. Después retratar aspectos colaterales. Una vez conseguido esto ¿Cómo se cuenta? La sensibilidad viene después. A ti mismo como fotógrafo algunas imágenes te parecen excesivas".

Este retorno a propuestas informativas muy anteriores no es equiparable a los planteamientos que se reproducen en el primer lustro de los 70 que están claramente propiciados por el mimetismo de unas rutinas enquistadas por una prolongada censura de un régimen político. Tampoco con las fórmulas de los inicios de la Transición donde cubrir todos los atentados resultaba una hazaña difícil a causa del incremento en el número de sucesos. El periodista Arcadi Espada indica que "en El País Vasco parecía haber más terroristas que periodistas" (2000: 16). El hecho de que el volumen de noticias fuera tan abundante conllevó a que se editasen sin una línea coherente donde se entremezclan fotos, absolutamente desgarradoras que hoy estarían vetadas, con la ausencia informativa de víctimas sin derecho a una imagen. A veces incluso se confunde

${ }^{6}$ Fernández, Juan Ignacio: entrevista personal (Bilbao, julio de 2002). 
la identidad de los retratados. Las omisiones o equívocos no están directamente relacionados con la mesura informativa, sino con la escasez de medios, falta de infraestructuras y el contexto social, porque cuando el fotógrafo se sitúa en el escenario del atentado opta por encuadrar las escenas más dramáticas. El periodista, Javier Pagola señala que "hasta más o menos el año 1987, hasta esa fecha, más que víctimas había muertos, reflejados en fotos tremendas. Muertos por disparos a bocajarro, con la cara desencajada. No había pudor a la hora de publicar esas fotos" (2003: 65).

La autocensura de los 90 se produce de forma paulatina. Durante los primeros años sólo se materializa en buenas intenciones focalizadas en no mostrar que cohabitan con las tomas de cuerpos sin vida reproducidas bajo idénticos parámetros que las de la década anterior.

Las formas de autocensura más frecuentes fijan un descenso del dramatismo y se concretan en dos aspectos. Por un lado, la desaparición del cadáver del encuadre y por otro, una mostración más sutil. Este carácter tenue se consigue mediante diversas fórmulas como son editar la instantánea de la víctima a mayor distancia narrativa, o con un incremento de la falta de nitidez, o colocando obstáculos entre la cámara y el asesinado para lograr que gracias al punto de vista el cadáver se reproduzca oculto o semioculto. Una última opción es retratar al fallecido, pero cubierto, pretendiendo que pase inadvertido. Se advierte, por tanto una limitación por parte de los propios medios instaurando una vertiente donde prevalece lo humano sobre la profesional. Un estudio de carácter cuantitativo ratifica esta afirmación donde se concluye que: "por lo que respecta al contenido de las fotografías, la unanimidad de los medios es prácticamente total: después del asesinato de Blanco descienden notablemente las fotografías de estragos y aumentan notablemente también las que recogen escenas de corte humano (Caminos, 2013b: 159). De acuerdo con estos autores y siguiendo también a Kepplinger y Habermeier el asesinato del concejal de Ermua puede definirse como un key event (2013:5).

El hecho de que se omita el cadáver in situ implica el establecimiento de unos patrones visuales que le reemplazan y que formarán parte del imaginario a partir de este momento. La mayoría evidencian una vuelta a tiempos pasados. El más significativo de estos arquetipos es publicar la imagen del herido en lugar del asesinado. Se trata de un mecanismo que sirve para manifestar una situación esperanzadora. Esto supone una inversión en relación a la década anterior en la que mostrar el cadáver era imprescindible. Esta predilección por las instantáneas de heridos es paradigmática en las imágenes del 16 de abril de 1991 del atentado a Koro Villamudria porque son los hermanos de ésta, que están siendo atendidos por los servicios sanitarios, los que desplazan a la toma de la víctima que sólo se observa en una foto tamaño cané. Otra propuesta en este mismo sentido es la de Deia del 22 de junio de 1993 donde se representa la muerte de seis militares y un civil mediante el rostro ensangrentado de una niña. Este mismo diario imprime el 30 de julio de 1994 una fotografía de una mujer con el rostro también manchado de sangre para ilustrar el asesinato de Francisco Veguillas, Francisco Martín y César García.

Otro motivo sustitutivo de la imagen del cadáver en el lugar del atentado es la del vehículo destrozado que ha servido como arma del atentado. El aumento de coches- 
bomba hace que se conviertan en auténticos protagonistas de la cobertura informativa, como en el que fallecen seis policías en Sabadell del que se hacen eco todos los medios analizados.

El lugar de los hechos desértico vuelve a ser una figura que se recupera. Se trata de unas tomas caracterizadas por la calidad y el detalle que no se asemejan a las de los años 70 más que en la ausencia de contenidos. La imagen que edita El Correo el 3 de septiembre de 1990 en la que se muestra el lugar del atentado donde fallecieron José Manuel Alba y Luis Alberto Sánchez a través de un subencuadre constituido por la garita que fue el blanco del coche-bomba que lanzaron los terroristas, corrobora este renovado concepto.

Frente a este escenario del suceso aséptico, en el cual ha desaparecido nuevamente el cadáver, nos encontramos con ese mismo espacio poblado por diferentes profesionales desempeñando su trabajo. Bomberos, policías, personal sanitario o voluntarios se entremezclan intentando hallar algún rastro. Este contraste entre estas imágenes basadas en la acción y el gentío y las que se obtienen cuando todo ha pasado, evidencian la intencionada omisión del cadáver.

Otra figura a la que el informador gráfico recurre para reemplazar el cuerpo sin vida es a la del policía como indicativo del lugar del asesinato. No se trata de un patrón nuevo, ya vimos que en los 70 era una fórmula muy habitual, que fue eclipsada por el cadáver de la víctima y por el miedo a ser reconocido y por tanto, a ser un nuevo objetivo de los terroristas. En los 90 se retorna a este tipo de imagen pero con una peculiaridad, los policías permanecen en todos los casos de espaldas a la cámara. Así recoge Deia el 14 de enero de 1995 a Rafael Leyva Loro observando donde perdió la vida su compañero, o en idéntica posición a un miembro de la ertzaintza mirando hacia el sitio donde se localizó a Miguel Ángel Blanco Villar el 13 de julio de 1997.

La autocensura por parte del informador es incuestionable, pero donde no se alcanza un acuerdo es en las causas que propician esta situación. J. Ignacio Fernández sitúa al lector como clave de este retraimiento: "La autocensura se produce por razones de mercado. El hecho de que los lectores sean reacios a imágenes muy duras es un factor fundamental para que la presencia de fotos violentas sea menor. Sobre todo si las víctimas son cercanas" (Ibídem). Por su parte, Javier Pagola focaliza las razones en el hecho de que se ha incrementado el círculo de las posibles víctimas: "Últimamente, por lo menos, nos hemos humanizado un poco, no sé si porque desde 1995-1996 se ha ampliado el abanico de víctimas y de amenazados por ETA, que afecta a representantes de los medios de comunicación, a políticos, incluidos concejales diputados o incluso a amigos de periodistas" (2003: 69).

Desde esta perspectiva subyacen dos cuestiones. A la ya expuesta, la autocensura para no herir la sensibilidad de las víctimas se suma la del miedo del reportero a ser asesinado. José Manuel Gabriel, periodista especializado de Onda Cero, hace un recorrido por aquellos informadores que fueron intimidados por la banda terrorista hasta llegar a los que perdieron su vida: "La mayor deuda profesional la tenemos todos los periodistas y demócratas con quienes sucumbieron bajo el miserable hachazo del terrorismo: José M $\mathrm{M}^{\mathrm{a}}$ Portell Manso, director de La Hoja del Lunes de Bilbao, asesinado en 1978; José Luis López de Lacalle, columnista de El Mundo, muerto a tiros en An- 
doain en 2000; y Santiago Oleaga, director financiero de El Diario Vasco, acribillado por la espalda en 2001. Junto a esto, las sedes de una decena de medios de comunicación han sido objeto de atentados con explosivos y numerosos periodistas han tenido que dejar su tierra en los últimos años para poder seguir trabajando lejos de las amenazas" (2003:126).

A partir de ese momento

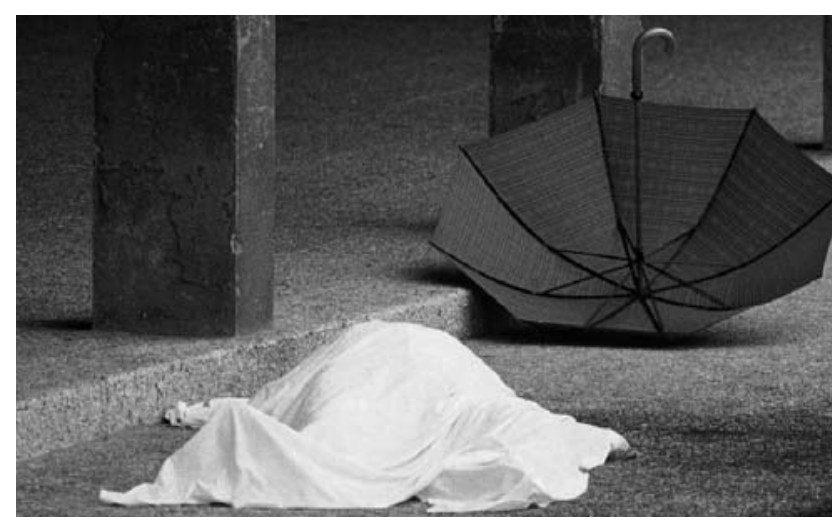

Fuente: El Correo, 8 de mayo de 2000 se plantea cuál debe ser el criterio profesional a la hora de publicar las imágenes de los atentados y dónde se sitúa la frontera entre la información y el morbo. Sobre el papel parece establecerse un acuerdo tácito. Entre periodistas pertenecientes a medios tan dispares como El Correo y El Mundo se responde de una manera similar aunque con matizaciones. Desde este último se determina: "Que la foto sirva para sensibilizar a la sociedad. No buscar el morbo, ni ampliar una foto a cuatro columnas que pueda vender mil periódicos. El criterio es que sea una foto lo más informativa posible y que haga ver la crueldad del terror" (Lázaro, 2003: 75). Por su parte, El Correo señala que: "Ahora los periódicos no queremos, ni consciente ni inconscientemente, ocultar ni minimizar el dolor de las víctimas. Pero creo que, por fin, después de tantos años, hemos aprendido a respetar su dolor"(Arnedo, 2003:27).

\section{Conclusiones}

En este recorrido por la historia de los atentados mortales de ETA hemos podido confirmar la estructura circular del tratamiento mediático del que partíamos. Además, apreciamos que las posibles misceláneas entre presencia y ausencia de las claves de este tema, el informador y la víctima in situ, han ido variando. En los 60 nos encontramos con un cadáver lejos de la toma fotográfica frente a un reportero sin señas de identidad. En el primer lustro de los 70 lo habitual fue que el cadáver apareciera muy excepcionalmente y el informador funcionase como garante de la noticia o estuviera en un segundo plano como señalizador. A partir de 1977 se combinan dos opciones, el fotógrafo evidente con un cadaver latente y viceversa. En 1981 los dos participan del mismo encuadre, para en los 90 retomar fórmulas del pasado en cuanto a la mostración del cadáver in situ. Por el contrario la figura del informador cobra más fuerza que nunca como artífice activo de unas tomas acordes con la sensibilidad de los tiempos y como protagonista del encuadre, como víctima. 


\section{Referencias bibliográficas}

ARMENTIA, José Ignacio, et al. (2012): El tratamiento de las muertes de ETA en la prensa vasca (1990-2010). Leioa, Servicio Editorial de la Universidad del País Vasco.

ARNEDO, Ángel (2003): "Medios de comunicción social y víctimas del terrorismo" en VVAA: Terrorismo, víctimas y medios de comunicación. Madrid, Fundación Víctimas del Terrorismo, pp. 25-28.

CAMINOS, José María et al. (2013a): "Los diarios vascos frente al terrorismo (1990, 2000, 2008 y 2009). Análisis de los editoriales sobre los atentados mortales de ETA”. Revista Latina de Comunicación Social, nº 68, pp. 1-26.

CAMINOS, José María, et al. (2013b): "El asesinato de Miguel Ángel Blanco como ejemplo de key event en el tratamiento mediático de los atentados mortales de ETA". AdComunica. Revista Cientifica de Estrategias, Tendencias e Innovación en Comunicación, $\mathrm{n}^{\circ}$ 6. Castellón, Universidad Complutense de Madrid y Universidat Jaume I, pp. 139-160.

DADER, José Luis (2007): "Del periodista pasible, la obviedad informativa y otras confusiones en el Estanco de noticias". Estudios sobre el Mensaje Periodístico, vol. 13. Madrid, Servicio de Publicaciones de la Universidad Complutense, pp. 31-53.

ESPADA, Arcadi (2000): en El País, 27 de agosto, p. 16.

FERNÁNDEZ BAÑUELOS, Juan Ignacio (1997): La transición del fotoperiodismo. Un acercamiento a las imágenes de los diarios vizcaínos durante el periodo 19751982. Leioa. Tesis doctoral (inédita). Universidad del País Vasco.

GABRIEL, José Manuel (2003): "El papel de la prensa en el combate al terrorismo" en VVAA: Terrorismo, víctimas y medios de comunicación. Madrid, Fundación Víctimas del Terrorismo, pp. 121-128.

GARCÍA, Mario R. (1984): Diseño y remodelación de los periódicos. Pamplona, Universidad de Navarra.

LÁZARO, Fernando y PAGOLA, Javier (2003): "La información en prensa" en VVAA: Terrorismo, víctimas y medios de comunicación. Madrid, Fundación Víctimas del Terrorismo, pp. 63-78.

OLIVARES, Rosa (2000): “Culpable o muerto”. Revista Exit, nº1, pp. 9-10.

PAREJO, Nekane (2003): Fotografia y muerte: representación gráfica de los atentados de ETA, 1968-1997, Universidad del País Vasco.

ROMERO, Emilio (1992): "Oficio, reportero gráfico: la tercera pata de periodismo". Revista AEDE, $\mathrm{n}^{\circ} 17$, p. 110-113. 